\title{
OTOMATİK DÜŞÜNCELERIN YORDAYICILIĞI: UMUT VE UMUTSUZLUK FARKI
}

\author{
PREDICTIVE ROLE OF AUTOMATIC THOUGHTS: DIFFERENCE BETWEEN HOPE AND \\ HOPELESNESS
}

\begin{abstract}
Murat ARTIRAN ${ }^{1}$ - Alperen ŞEKER ${ }^{2}$
$\ddot{O} z$

$\mathrm{Bu}$ çalışmanın temel amacı, bilişsel terapide tedavi uygulamalarının ana öğelerinden biri olan olumsuz otomatik düşüncelerin umut değişkeni ve umutsuzluk değişkeni ile ilişsisini ortaya koymaktır. Araştırmaya özel sektör çalışanlarından kolay örnekleme yöntemiyle seçilen 74'ü kadın 123 erkek olmak üzere toplam 197 katılımcı katılmıştır. Verilerin incelenmesinde Pearson korelasyon katsayısı ve çoklu doğrusal regresyon analizi kullanılmıştır. Elde edilen bulgulara göre olumsuz otomatik düşüncelerin, yaşam projesi ölçeği değişkenlerinden olan 'pozitif' umut değişkenini yordamadığı gözlenlenmiştir. Öte yandan umutsuzluk değişkeni ile güçlü bir ilişkisellik içinde olduğu ve bu değişkeni yordadığı bulunmuştur. Araştırma bulguları ışı̆̆ında olumsuz otomatik düşüncelerin psikolojideki pozitif yapılarla ilişkisellik içerisinde olduğu ancak bu değişkenleri etkilemediği söylenebilir. Gelecekteki çalışmalarda bilişsel terapinin sadece psikolojideki olumsuz değişkenlerle değil pozitif psikoloji değişkenleri ile test edilmesi önerilebilir.
\end{abstract}

Anahtar Kelimeler: otomatik düşünceler, umut, umutsuzluk, bilişsel terapi

\begin{abstract}
The aim of this study was to determine the relationships among negative automatic thoughts which is one of the main components of the treatment applications in cognitive therapy, hope and hopelessness variables. A total of 197 participants, 74 (female) and 123 (male), were selected from the private sector employees via convenient sampling method. Pearson correlation coefficient and multiple linear regression analysis were used to analyze the data. According to the findings, negative automatic thoughts did not predict the life project variables including 'positive' hope variable. On the other hand, negative automatic thoughts were found to be strongly correlated with hopelessness and predict this variable. According to the results, negative automatic thoughts are related to positive structures in psychology while don't affect these variables. In future studies, it is suggested to investigate cognitive therapy components (e.g. automatic thoughts) not only with negative variables in psychology but also with positive psychology variables.
\end{abstract}

Keywords: automatic thoughts, hope, hopelessness, cognitive therapy

\footnotetext{
${ }^{1}$ istanbul Arel Üniversitesi, dr.muratartiran@gmail.com, Orcid: 0000-0003-1996-024X

${ }^{2}$ Rasyonel Psikoloji Arş. Dan. Merkezi, alperenseker91@gmail.com, Orcid: 0000-0002-3016-8264
} 


\section{GİRIŞ}

Bilişsel Davranışçı Terapiler (BDT) 1960'lı yıllarda Albert Ellis tarafindan geliştirilen Rasyonel Duygucu Davranışçı Terapi (RDDT) ve Aaron Beck tarafından geliştirilen Bilişsel Terapi yaklaşımından doğmuştur (Ellis, 1994, 2003; Beck, 1995; Artıran, 2015). BDT irrasyonel düşünce yapıları ve insan psikolojisindeki işlevsel olmayan duygu ve davranışlarla ilgilenir. Her ne kadar BDT, ağırlıklı olarak psikopatoloji ve depresyon umutsuzluk, anksiyete, işlevsizlik gibi 'olumsuz' psikolojik yapılarla (Beck, 1963, 1976; Beck ve Emery, 2011) ilgileniyor olsa da son dönemdeki gelişmeler, psikolojideki pozitif yapılar üzerinde BDT araştırmacılarının ilgisinin çoğaldığını göstermektedir (Bannink, 2013). Bu durum da kişilerin yetenekleri, becerileri, pozitif duygu ve düşünceleri ve gelecekteki mutlu yaşamları üzerinde çalışmaların yoğunlaşılması gerekliliğini doğurmaktadır. Bilişsel davranışçı terapilerin insan psikolojisinin yetenek, beceri, sağlıklı duygular gibi pozitif özellikler (Snyder, İlardi, Cheavens ve Michael, 2000; Bannink, 2013) ve çalışma hayatı gibi ruh sağlığı alanı dışındaki yaşam alanları ile ilişkiselliğinin incelenmesi son yıllarda ele alınan konular arasındadır (Himle, Steinberger, Laviolette ve Golenberg, 2013). Çalışma hayatına yönelik olarak BDT uygulamalarının ve ölçme araçlarının yaygınlaştığı görülmektedir. Örneğin Wijhe, Peeters ve Schaufeli'in RDDT'nin kuramsal öngörülerine göre ortaya koyduğu Çalışma Bağımlığı İrrasyonel İnanışları Ölçeği, çalışanların fonksiyonel olmayan düşünce yapılarını ölçmek üzere geliştirilmiştir (2013). Öte yandan son yıllarda Bannink (2013), Padesky ve Mooneyi (2012), Artıran (2015) ve Greenberg (2015) gibi araştırmacılar pozitif psikolojinin bilişsel davranışçı terapi ile birlikte değerlendirildiği yeni terapötik yaklaşımlar önermiştir. Ancak bu çalışmaların deneysel ve diğer niceliksel araştırmalarla test edilmesine ve incelenmesine ihtiyaç vardır.

$\mathrm{Bu}$ çalışmada, olumsuz otomatik düşüncelerin, umut değişkeninin de içerisinde yer aldığı yaşam projesi değişkenleri ve umutsuzluk üzerinde sebep-sonuç ilişkisi ortaya konulmaya çalışılmıştır. Araştırılmak istenen konu bugüne kadarki bilişsel davranışçı terapi modellerinin negatif değişkenlerde olduğu gibi pozitif değişkenler üzerinde de etkin olup olmadığını ölçmektir. BDT terapilerinin ana unsularından biri olan olumsuz otomatik düşüncelerin, insanların kendini başarısız görme, aşırı genelleme ve abartma eğilimine yol açıp psikolojik bozukluklara ve işlevsel olmayan davranışlara yol açtıkları kabul edilir (Beck ve ark., 2011: 124; Murdock, 2012). Fennel'e (1996) göre, sağlıksız ve işlevsel olmayan duygulara yol açan olumsuz otomatik düşünceler "olumsuz" ve herhangi bir derin düşünme süreci içermezler ve ani olarak ortaya çıktıkları için de "otomatik" olarak adlandırılırlar. Olumsuz otomatik düşünceler; şu anki deneyimlerin yorumlanması, gelecekteki olaylara ilişkin kestirmeler ya da geçmişte olan şeylerin anımsanması biçiminde olabilir. Bilişsel davranışçı terapilerin çekirdek modeli $\mathrm{ABC}$ modelinde olumsuz otomatik düşüncelerin yeri "B" kısmındadır. ABC modeli, İngilizce'de Activating: Harekete geçiren olay veya tetikleyici, Beliefs: İnanışlar ve düşünceler, Consequences: duygusal, davranışsal ve bedensel sonuçlar olarak sembolleştirilmiştir. Olay veya tetikleyici, kişinin tecrübe ettiği durumu, inanışlar/düşünceler kişinin yaşadığ 1 olaya ilişkin yorum ya da düşüncesini, sonuç ise, olaya ilişkin kişinin verdiği davranışsal, fizyolojik ya da duygusal tepkiyi ifade etmektedir. ABC modelinin 'B'sinde analiz edilerek terapötik olarak müdahale edilmek istenen öğeler başta irrasyonel inanışlar (aşırı talepkarlık, rahatsız olmaya katlanamamak, felaketleştirme ve kendini/diğerlerini/hayatı aşağılamak) (DiGiuseppe, Doyle, Dryden ve Backx, 2014) olmak üzere olumsuz otomatik düşünceler, ara inançlar, algılar, çıkarımlar ve çocukluk dönemlerinden gelen çekirdek inanışlardır (sevilmeme, çaresizlik ve değersizlik inanışları) (Beck, 2001). RDDT ve BDT’ye göre bireyler çevrelerinde maruz kaldığı olayların anlamını sürekli değerlendirir ve bilişsel süreçlerine sık sık duygusal tepkiler eşlik eder (Wright, Basco ve Thase, 2006). BDT yöntemleri yardımıyla bireyin, kendisini olumsuz yönde etkileyen duygu, düşünce ve davranışlarla baş etmesi sağlanırken, problemlerin yinelenmesinin de engellendiği varsayılmaktadır (Gladding 2015; Smith ve ark. 2012; Akt. Usta, 2017).

$\mathrm{Bu}$ araştırmanın değişkenlerinden biri olan 'umut' kavramı pozitif psikolojinin (Seligman ve Csikszentmihalyi, 2000) ilgi gösterdiği konulardandır. Umut, kişinin arzu ettiği hedefler ve bu 
hedeflere giderken yapabileceklerine dair algıladığı kapasitesi, dolayısıyla bu hedeflere ulaşmadaki olasılık ile ilgili bir değişkendir (Snyder İlardi, Cheavens ve Michael, 2000). Umut kavramı pozitif psikolojide çeşitli yönlerden araştırılan bir konudur. Örneğin Şimşek (2009), içerisinde umut kavramını da işlediği ontolojik iyi oluş kavramını ortaya atmıştır. Ontolojik iyi oluş, kişinin kendi yaşamının bir proje olarak değerlendirilmesine odaklanır ve yaşam projesini geçmiş, gelecek ve şimdiki zaman ile birlikte ele alarak yaşamı bütünsel olarak değerlendirir. Geçmiş zaman penceresinden bakıldığında ontolojik iyi oluş; değişen duygulardan oluşmaktadır. Şimdiki zaman penceresinden bakıldığında bireyin projeyi devam ettirmeye olan motivasyonu olarak değerlendirilmektedir. Gelecek zaman kapsamında bakıldığında ise, umut, umutlu olmak ile yakından ilişsilidir ve iyimser duyguların bütünü olarak düşünülmektedir (Şimşek, 2009). Umut boyutunun; amaca yönelik motivasyon ve alternatif yollar olmak üzere iki yönü bulunmaktadır (Snyder, Harris, Anderson, Holleran, Irving, Sigmon, Bshinobu, Gibb, Langelle ve Harney, 1991). İrade gücü amaca yönelten bir enerji iken, yol gücü amaçları gerçekleştirmek için planlanan alternatif yolları ifade eder. Diğer bir değişle umut; başarıya giden yolun belirlenmesini, netleştirilmesini ve sürdürülmesini sağlayacak niyeti göstermektedir (Snyder ve ark., 1991).

Umut değişkeninden farklı olarak Beck Umutsuzluk Ölçeği ile kavramsallaştırmaya çalışılan 'umutsuzluk' kavramı, kişinin geçmişte yaşamış olduğu olumsuz olaylara dayanır ve birey, bir taraftan karşılaştığı stres yaratıcı olayların sebebini düşünürken diğer taraftan olayın sonucunda ortaya çıkacak olan gelecekteki olumsuz sonuçları düşünür (Şahin, 2009). Umutsuzluk kavramı 1960'lı yıllarda depresyonun nedenleri üzerine yapılan teorik açıklamalarla birlikte ortaya konmuştur. $\mathrm{Bu}$ kuramlardan en yaygın olanlardan birisi Beck tarafindan geliştirilen Bilişsel Terapi'dir. Kuram umutsuzluğu, çoğunlukla depresyonun başlangıç ve sürdürülme sürecinde öncelikli sebep olarak görür. Umutsuzluk, kişinin geleceğe yönelik olumsuz beklentiler geliştirmesi ve kendi kapasitesini var olandan aşağı görmesi olarak tanımlanır (Henkel, Mergl, Kohnen, Maier, Möller ve Hegerl 2003). Umutsuzluk, kişilerin problemlerini hiçbir zaman çözemeyeceklerine, başarısızlıklarını hiçbir zaman yenemeyeceklerine inanması, gerçekçi bir neden olmadığı halde hayatlarına yanlış anlamlar yüklemesi ve amacına ulaşmak amacıyla çaba göstermediği halde bunlardan negatif sonuçlar beklemesi olarak tanımlanmaktadır (Beck, 1976). Bireyler kendilerini umutsuz hissettiklerinde, sahip olduğu planları somutlaştırmada ve sorunlarının çözümünde alternatif yöntemler ortaya koymada zorlanabilirler. Problemlerle karşılaştıklarında, alternatif çözümler göremedikleri için umutsuzluk duygusu daralmaya yol açar.

$\mathrm{Bu}$ araştırmanın örneklem grubu çalışma hayatındaki beyaz ve mavi yakalı çalışanlardan kolay örnekleme yöntemi ile seçilmiştir. Beyaz yakalı çalışanlar ofis ortamında, mavi yakalı çalışanlar ise sahada veya üretim tezgahı başında zihin gücüne oranla daha fazla beden gücüne dayalı çalışanlar olarak tanımlanabilmektedir. Çalışma hayatı yaşam döngüsünde önemli bir yer tutmaktadır. Çalışmak, fiziksel, bilişsel ve ruhsal bir çaba ile kişinin kendisine ya da başkalarına değer ifade eden mal ve hizmetin üretim faaliyetleridir (Tınar, 1999). Belirli bir örgütsel ortamda ve belirli bir zamanda gerçekleştirilen görev olarak kabul edilen çalışma, içinde bulunulan örgüte sağlanan katkı ya da değer olarak tanımlanabilir (Eğinli, 2009). Çalışanlarda bulunan umutsuzluk, bireyin çalışma hayatını ve özel hayatını olumsuz yönde etkileyerek bireylerin işlevselliklerini bozmaktadir.

Alan yazında olumsuz otomatik düşüncelerin umutsuzluğu yordadığına dair birçok araştırma olduğu gözlemlenmektedir, ancak umut değişkeni ile ilgili sınırlı sayıda çalışma vardır. BaBamiri, Vatankhah, Jahandizi, Nemati ve Darvishi (2011) olumsuz otomatik düşüncelerin umut değişkeni üzerinde etkisi incelenmiş ancak anlamlı sonuçlara erişmemişlerdir. Kumcağız, Şahin Alakuş ve Akbaş'ın (2017) çalışmasında ise umut ile olumsuz otomatik düşünceler puanları arasında negatif yönde orta düzeyde anlamlı bir ilişki olduğu ortaya konulmasına rağmen yordayıcı bir ilişki gözlemlenmemiştir. $\mathrm{Bu}$ araştırmada olumsuz otomatik düşüncelerin alan yazındaki diğer araştırmalarda olduğu gibi umutsuzluk değişkeni ile ilişsisi test edilmiş, bunun yanında umut değişkeni üzerinde ne oranda etkisi olduğu incelenmiştir. 


\section{YÖNTEM}

\section{1. Çalışma Grubu}

Araştırmada İstanbul, İzmir ve Aydın illerinde özel sektör çalışanlarından kolaydan örnekleme yöntemiyle seçilen \%37.6'sı (74) kadın ve \%62.4'ü (123) erkek olmak üzere 197 kişiden oluşmuştur. Katılımcılar hem ofis ortamında çalışanlar ve hem de sahada veya üretim tezgahı başında zihin gücüne oranla daha fazla beden gücüne dayalı çalışanlardan oluşmaktadır. Katılımcıların yaş ortalaması 30.7'dir (SS: 8.204). Araştırmaya katılan çalışanların $11^{\prime} \mathrm{i}(\% 5.6)$ ilk öğretim, 58’i (\%29.4) lise, 47’si (\%23.9) ön lisans, 71'i (\%36.09) lisans ve 10’u (\%5.1) ise yüksek lisans derecesine sahiptir.

\subsection{Analiz Stratejisi}

Verilerin normal dağılıma uygunluğunun kontrol edilmesi amaciyla Bartlett Sphericity testi ve KaiserMeyer-Olkin (KMO) testleri kullanılmıştır. KMO değeri .91 çıkmıştır, KMO katsayısının 0.60 ve üzeri olması (Field, 2000) ve Barlett testinin anlamlı çıkması (Tatlidil, 2002) verilerin normal dağıldığını göstermiştir. Dolayısıyla verilerin analizinde parametrik testler kullanılmıştır. Araştırmanın değişkenleri arasında pearson korelasyon analizi ve çoklu lineer regresyon analizi gerçekleştirilmiştir. Bağımlı değişken üzerinde birden fazla bağımsız değişkenin toplu etkisi araştırılacağından çoklu regresyon modeli tercih edilmiştir.

\subsection{Veri Toplama Araçları}

Veri toplama aşamasında, çalışanlara uygulanan Kişisel Bilgi Formu, olumsuz otomatik düşünceleri ölçmek için Otomatik Düşünceler Ölçeği, içerisinde 'umut' değişkeninin de yer aldığı psikolojideki pozitif değişkenleri ölçmek için Yaşam Projesi Ölçeği, 'umutsuzluk' değişkenini ölçmek için de Beck Umutsuzluk Ölçeği kullanılmıştır. Anket formlarının doldurulması 20 dakika sürmüştür. Formlar doldurulmadan önce katılımcılara araştırmanın amacı, katılmak zorunda olmadıkları ve gönüllü olarak bilimsel bir araştırmaya destek vermiş olacakları ve istedikleri zaman soruları cevaplamayı bırakabilecekleri sözlü olarak bildirilmiştir. 3 katılımcının anketi, anketleri tam olarak doldurmadıkları için değerlendirmeye alınmamıştır.

\subsubsection{Otomatik Düşünceler Ölçeği}

Hollan ve Kendal (1980) tarafindan geliştirilen Otomatik Düşünceler Ölçeği (ODÖ) bireyin kendine yönelik olumsuz değerlendirmelerin sıklığını ölçmeyi amaçlamaktadır. Ölçek beş alt faktörden ve 30 maddeden oluşmaktadır. Likert tipi olan bu ölçek 1 ile 5 arası puanlanır ve katılımcıdan her madde için birini seçip işaretlenmesi istenmektedir. Ölçeğin alt boyutları: "Kişinin Kendine Yönelik Negatif Duygu ve Düşünceleri”, "Şaşkınlık - Kaçma Fantezileri”, "Kişisel Uyumsuzluk ve Değişme İstekleri”, "Yalnızlık - İzolasyon" ve "Ümitsizlik" olarak isimlendirilmiştir (Akt. Savaşır ve Şahin, 1997). Ölçekten ve alt ölçeklerden edinilen toplam puanların yüksekliği, bireyde olumsuz otomatik düşüncelerin yaygın bir şekilde ve sıklıkla ortaya çıktığını göstermektedir (Savaşır ve Şahin, 1997). Otomatik Düşünceler Ölçeği'nin Türkçe’ye uyarlaması, Şahin ve Şahin (1992), tarafından gerçekleştirilmiştir. Türkçe'ye uyarlama çalışmalarında Cronbach Alfa iç tutarlılık katsayısı Şahin ve Şahin tarafından (1992) 93 olarak saptanmıştır. Bu araştırmada ölçeğin iç tutarlılık katsayısı .95 olarak hesaplanmıştır.

\subsubsection{Yaşam Projesi Ölçeği}

Yaşam Projesi ölçeği, Şimşek ve Kocayörük (2013) tarafından geliştirilmiştir. Ölçek kişinin ontolojik iyi oluşunu yani yaşam projesini geçmiş, şimdi ve geleceği değerlendirerek ölçmeyi amaçlar. Geçerlik güvenilirlik çalışmaları yapılan ölçek 4 alt faktöre ayrılan 24 maddeden oluşmaktadır. Likert tipi olan bu ölçek 1 ile 5 arası puanlanır ve katılımcıdan her madde için kendisi için en uygun olanı seçip işaretlenmesi istenir. Ölçeğin alt boyutları: "Pişmanlık" olumsuzluk belirten 7 maddeden, "Harekete Geçme-Aktivasyon" 1'i olumsuz 4'ü olumlu anlam ifade eden 5 maddeden oluşmaktadır. "Hiçlik" olumsuzluk belirten 6 maddeden oluşmaktadır, "Umut" olumlu 
anlam ifade eden toplamda 7 maddeden oluşmaktadır. Bu araştırmada ölçeğin iç tutarlılık katsayısı .71 olarak hesaplanmıştır.

\subsubsection{Beck Umutsuzluk Ölçeği (BUÖ)}

Beck Umutsuzluk Ölçeği (BUÖ) Beck, Lester ve Trexler (1974) tarafından geliştirilmiştir. Ölçeğin Türkçe'ye uyarlama çalışmaları Seber (1991) ve Durak ve Palabıyıklığlu (1993) tarafından gerçekleştirilmiştir. Ölçekte katılımcıdan kendisi için uygun gelen ifadeleri "evet", uygun olmayanları ise "hayır" olarak işaretlemesi istenir. 11 doğru, 9 yanlış anahtar yanıtı olan bu ölçek toplamda 20 doğru-yanlış önermeden oluşmuştur. Anahtara uyumlu her yanıt için 1 puan, uyumsuz her yanıt için ise 0 puan verilerek puanlaması yapılır ve elde edilen aritmetik toplam "Umutsuzluk Puanı" olarak kabul edilmektedir. Maddelerden 5'i gelecekle ilgili duyguları, 8'i motivasyon kaybını, 5'ide gelecekle ilgili beklentileri ifade eder. Alınan puanlar yüksek olduğunda bireydeki umutsuzluğun yüksek çıtı̆̆ı varsayılır. Türkiye'de geçerlik ve güvenirlik çalışmasında ölçeğin iç tutarlılık katsayısı .85 olarak hesaplanmıştır. Bu araştırmada ise .83 olarak hesaplanmıştır.

\section{BULGULAR}

Tablo 1'de Otomatik Düşünceler Ölçeği'nin alt maddeleri (olumsuz düşünceler, şaşkınlık, uyumsuzluk, yalnızlık, ümitsizlik) ve yaşam projesi ölçeğinin alt maddeleri (pişmanlık, aktivasyon, hiçlik ve umut) ile Beck Umutsuzluk Ölçeği toplam puanları arasında yapılan pearson korelasyon testi sonuçları incelenmiştir. Değişkenler arasında korelasyon katsayısı 0,31 - 0,49 arasında ise zayıf, 0,50-0,69 arasında ise orta derecede, 0,70-1,00 arasında olması ise yüksek ilişkinin var olduğunu göstermektedir (Sönmez ve Alacapınar, 2011). Otomatik düşünceler ölçeğinin alt faktörlerinin yaşam projesi değişkenleri olan pişmanlık ile $r=.47$ ile $r=.57 \quad(p<0.05)$ arasında değişen katsayılarda orta düzeyde ilişkisellik içerisinde olduğu bulgulanmıştır. ODÖ’nün alt faktörlerinin yaşam projesin değişkeni olan aktivasyon ile $r=-0.34$ ile $r=-0.48(p<0.05)$ arasında değişen katsayılarda ilişkisellik içerisinde olduğu hesaplanmıştır. Ölçeğin alt faktörlerinin yaşam projesin değişkeni olan hiçlik ile $r=.50$ ile $r=.60(p<0.05)$ arasında değişen katsayılarda ilişkisellik içerisinde olduğu bulgulanmıştır. Umut değişkeni ile de $r=-0.33$ ile $r=-0.37(p<0.05)$ arasında değişen katsayılarda zayıf düzeyde ilişkisellik içerisinde olduğu bulgulanmıştır. ODÖ'nün alt faktörlerinin, Beck Umutsuzluk Ölçeği ile ilişkisinde ise $r=.41$ ile $r=.50(p<0.05)$ arasında değişen katsayılarda ilişkisellik olduğu görülmüştür. 
Tablo 1. Değişkenler Arası Korelasyon Analizi

\begin{tabular}{|c|c|c|c|c|c|c|c|c|c|c|c|c|}
\hline & $\mathrm{M}$ & SD & 1 & 2 & 3 & 4 & 5 & 6 & 7 & 8 & 9 & 10 \\
\hline 1.OD Olumsuz & 45.67 & 0,62 & 1 & & & & & & & & & \\
\hline 2.OD Şaşkınlık & 40.22 & 0,80 & $0,656^{* *}$ & 1 & & & & & & & & \\
\hline 4.OD Yalnızlık & 126.77 & 0,85 & $0,640 * *$ & $0,731 * *$ & $0,649 * *$ & 1 & & & & & & \\
\hline 5.OD Ümitsizlik & 20.61 & 0,76 & $0,606^{* *}$ & $0,556^{* *}$ & $0,581 * *$ & $0,568 * *$ & 1 & & & & & \\
\hline 6. YP Pişmanlık & 21.89 & 0,71 & $0,528 * *$ & $0,556^{* *}$ & $0,571 * *$ & $0,550 * *$ & $0,479 * *$ & 1 & & & & \\
\hline 7. YP Aktivasyon & 21.84 & 0,99 & $-0,342 * *$ & $-0,467 * *$ & $-0,484^{* *}$ & $-0,368 * *$ & $-0,369 * *$ & $-0,542 * *$ & 1 & & & \\
\hline 8. YP Hiçlik & 28.92 & 0,77 & $0,508 * *$ & $0,609 * *$ & $0,525 * *$ & $0,581 * *$ & $0,554 * *$ & $0,689 * *$ & $-0,522 * *$ & 1 & & \\
\hline 9. YP Umut & 31.92 & 1,16 & $-0,334 * *$ & $-0,368 * *$ & $-0,355^{* *}$ & $-0,366^{* *}$ & $-0,343 * *$ & $-0,523 * *$ & $0,699 * *$ & $-0,511 * *$ & 1 & \\
\hline 10. BU & 45.23 & 4,24 & $0,445^{* *}$ & $0,429 * *$ & $0,455^{* *}$ & $0,501 * *$ & $0,412 * *$ & $0,534 * *$ & $-0,501 * *$ & $0,540 * *$ & $-0,552 * *$ & 1 \\
\hline
\end{tabular}

**p<.01, *p<.05 anlam düzeyinde istatistiksel olarak anlamlıdır. Not: OD Negatif: Otomatik Olumsuz Düşünceler, OD Şaşkınlık: Otomatik Şaşkınlık Düşünceleri, OD Uyumsuzluk: Otomatik Uyumsuzluk Düşünceleri, OD Yalnızlık: Otomatik Yalnızlık Düşünceleri, OD Ümitsizlik: Otomatik Ümitsizlik Düşünceleri, YP Pişmanlık: Yaşam Projesi Pişmanlık, YP Aktivasyon: Yaşam Projesi Aktivasyon, YP Hiçlik: Yaşam Projesi Hiçlik, YP Umut: Yaşam Projesi Umut, 
Araştırmanın çoklu regresyon bulguları ise şu şekilde değerlendirilmiştir: Bağımlı değişkenin değerinin diğer bağımsız değişkenin bağlı olarak yordanabilmesi için regresyon analizleri kullanılır. Regresyon analizi ile elde edilen katsayı " $R$ " değeridir ve bu katsayı değişimlerin yüzde kaçının diğer değişken tarafindan açıklanabileceğini belirten katsayı olup 0 ila 1 arasında değer alır (Balcı, 2009).

Tablo 2. Olumsuz Otomatik Düşünceler ile Umutsuzluk Regresyon Analizi

\begin{tabular}{|c|c|c|c|c|c|c|c|c|}
\hline Model & $\begin{array}{c}\text { Bağımlı } \\
\text { Değişkenler }\end{array}$ & $\begin{array}{c}\text { Bağımsız } \\
\text { Değişkenler }\end{array}$ & $\mathbf{F}$ & $p$ & $\mathbf{R}^{2}$ & $\boldsymbol{\beta}$ & $\begin{array}{c}\mathrm{t}- \\
\text { değeri }\end{array}$ & $p$ \\
\hline \multirow{5}{*}{ Model I } & \multirow{5}{*}{$\begin{array}{l}\text { Beck } \\
\text { Umutsuzluk }\end{array}$} & $\begin{array}{l}\text { OD- Olumsuz } \\
\text { düşünceler }\end{array}$ & \multirow{5}{*}{24,13} & \multirow{5}{*}{$0,00 *$} & \multirow{5}{*}{0,45} & $-0,06$ & $-0,62$ & 0,54 \\
\hline & & OD- Şaşkınlık & & & & 0,01 & 0,12 & 0,91 \\
\hline & & OD- Uyumsuzluk & & & & 0,15 & 1,67 & 0,10 \\
\hline & & OD- Yalnızlık & & & & 0,34 & 3,32 & $0,00^{*}$ \\
\hline & & OD- Ümitsizlik & & & & 0,28 & 2,92 & $0,00^{*}$ \\
\hline
\end{tabular}

**p<.01, *p<.05. OD: Olumsuz Otomatik Düşünceler

Tablo 2'de, umutsuzluk bağımlı değişkeni, olumsuz düşünceler, şaşkınlık, uyumsuzluk, yalnızlık, ümitsizlik bağımsız değişkenleri ile açıklanmıştır. Model anlamlı olup modelin $\mathrm{R}^{2}$ değeri 0,45 olarak bulgulanmıştır. Bağımsız değişkenler, bağımlı değişken olan umutsuzluk değişkendeki toplam varyansın \%45'ini açıklamaktadır. Modelde yer alan bağımsız değişkenlerden yalnızlık ve ümitsizlik, umutsuzluk değişkenini anlamlı bir şekilde doğru yönlü olarak sirasıyla 0.34 ve 0.28 birim etkilerken, diğer bağımsız değişkenler ile umutsuzluk arasında bir ilişki bulunamamıştır.

Tablo 3. Olumsuz Otomatik Düşünceler ile Yaşam Projesi Arasındaki Regresyon Analizi

\begin{tabular}{|c|c|c|c|c|c|c|c|c|}
\hline Model & $\begin{array}{l}\text { Bağımlı } \\
\text { Değişkenler }\end{array}$ & $\begin{array}{l}\text { Bağımsız } \\
\text { Değişkenler }\end{array}$ & $\mathbf{F}$ & $\mathbf{p}$ & $\mathbf{R}^{2}$ & Katsayı & $\begin{array}{c}\text { t- } \\
\text { değeri }\end{array}$ & $\mathbf{p}$ \\
\hline \multirow{5}{*}{$\begin{array}{l}\text { Model } \\
\text { II }\end{array}$} & \multirow{5}{*}{$\begin{array}{l}\text { Yaşam } \\
\text { Projesi }\end{array}$} & $\begin{array}{l}\text { OD- olumsuz } \\
\text { düşünceler }\end{array}$ & \multirow{5}{*}{2,66} & \multirow{5}{*}{$0,02^{*}$} & \multirow{5}{*}{0,07} & 0,15 & 1,21 & 0,23 \\
\hline & & OD- Şaşkınlık & & & & 0,22 & 1,55 & 0,12 \\
\hline & & OD- Uyumsuzluk & & & & $-0,31$ & $-2,5$ & $0,01 *$ \\
\hline & & OD- Yalnızlık & & & & 0,07 & 0,48 & 0,63 \\
\hline & & OD- Ümitsizlik & & & & 0,04 & 0,3 & 0,76 \\
\hline
\end{tabular}

Tablo 3 incelendiğinde bu araştırmanın konusu olan olumsuz otomatik düşüncelerin umut değişkeni üzerinde etkisi olmadığı görülmektedir. Yaşam projesi ölçeği değişkenlerinin bağımlı değişken olduğu ve olumsuz otomatik düşünceler alt faktörleri olan olumsuz düşünceler, şaşkınlık, yalnızlık, ümitsizlik bağımsız değişkenlerinin bağımsız değişken olduğu regresyon modelinde ODÖ alt faktörlerinden sadece uyumsuzluk değişkenin yaşam projesini yordadığı bulunmuştur. Bu bulguların yanında Yaşam Projesi alt faktörü olan umut üzerinde Otomatik Düşünceler Ölçeği alt faktörlerinin etkisi çoklu regresyon analizi ile incelenmiş ve sonuçların uyumsuzluk ve ümitsizlik haricinde umut değişkenini yordayan bir 
alt faktör olmadığını ortaya koymuştur (Tablo 4). Otomatik düşünceler ölçeği değişkenleri, bağımlı değişken umut değişkendeki toplam varyansın \%21'ini açıklamaktadır.

Tablo 4. Olumsuz otomatik düşüncelerin umut üzerindeki etkisi.

\begin{tabular}{|c|c|c|c|c|c|c|c|c|}
\hline Model & $\begin{array}{c}\text { Bağımlı } \\
\text { Değişkenler }\end{array}$ & $\begin{array}{c}\text { Bağımsız } \\
\text { Değişkenler }\end{array}$ & $\mathbf{F}$ & $\mathbf{p}$ & $\mathbf{R}^{2}$ & Katsayı & $\stackrel{t-}{\text { değeri }}$ & $\mathbf{p}$ \\
\hline \multirow{5}{*}{$\begin{array}{l}\text { Model } \\
\text { III }\end{array}$} & \multirow{5}{*}{ Umut } & $\begin{array}{l}\text { OD- olumsuz } \\
\text { düşünceler }\end{array}$ & \multirow{5}{*}{9,75} & \multirow{5}{*}{$0,00 *$} & \multirow{5}{*}{0,21} & 0,15 & 1,21 & 0,35 \\
\hline & & OD- Şaşkınlık & & & & 0,22 & 1,55 & 0,43 \\
\hline & & OD- Uyumsuzluk & & & & $-0,31$ & $-2,5$ & $0,04 *$ \\
\hline & & OD- Yalnızlık & & & & 0,07 & 0,48 & 0,19 \\
\hline & & OD- Ümitsizlik & & & & 0,04 & 0,3 & $0,02 *$ \\
\hline
\end{tabular}

**p<.01, *p<.05. OD: Olumsuz Otomatik Düşünceler

\section{BULGULAR}

$\mathrm{Bu}$ araştırmada çalışanlardan elde edilen veriler ile olumsuz otomatik düşünceler, yaşam projesi değişkenleri ve umutsuzluk ile birlikte incelenmiştir. Bu amaçla korelasyon ve çoklu regresyon analizleri gerçekleştirilmiştir. Alan yazın incelendiğinde olumsuz otomatik düşünceler ile yaşam projesi değişkenleri (aktivasyon, pişmanlık, hiçlik, umut) arasındaki ilişkiselliği inceleyen başka bir çalışma yoktur. Özetle bu araştırmanın üç ana bulgusu şu şekilde sıralanabilir: (1) olumsuz otomatik düşünceler ile umutsuzluk arasında ilişkisellik ve yordayıcı etki vardır, (2) olumsuz otomatik düşünceler ile yaşam projesi arasında ilişkisellik olmasına rağmen, olumsuz otomatik düşünceler uyumsuzluk değişkeni haricinde, yordayıcılık etkisi yoktur, (3) olumsuz otomatik düşünceler uyumsuzluk ve ümitsizlik değişkeni haricinde umut değişkenini yordayan bir otomatik düşünceler ölçeği değişkeni yoktur.

Sonuçlar, olumsuz otomatik düşüncelerin, yaşam projesi alt faktörleri ve umutsuzluk puanları arasında istatistiksel olarak anlamlı bir ilişki bulunduğunu göstermiştir. Olumsuz otomatik düşünceler ve umutsuzluk arasında pozitif yönde orta derecede, anlamlı ilişki bulunmuştur. Alan yazında olumsuz otomatik düşünceler ve umutsuzluk arasında anlamlı ilişkiler bulunduğunu ortaya koyan birçok çalışma vardır (Tümkaya, 2011; Çakar, 2014 Stiles ve Götestam, 1989). Örneğin Aydın (1990) tarafından üniversite öğrencilerine yönelik yapılan araştırmada olumsuz otomatik düşünceler ve umutsuzluk arasında pozitif ilişki bulunmuştur. Aynı şekilde, Aras'ın (2011) çalışması bu araştımanın sonuçlarını destekler nitelikte, olumsuz otomatik düşünceler ile umutsuzluk arasındaki pozitif ilişkiyi ortaya koymuştur. Hankin ve Abramson (2001), ergenlik döneminde depresyon ve umutsuzluğu inceledikleri araştırmalarında; savunmasız olduklarını düşünen kişilerin olumsuz düşüncelerinin olduğu durumlarda umutsuzluk duygusu içinde bulunduklarını öne süren umutsuzluk teorisinin, ilk olarak depresyonun alt tiplerindeki belirtilere ve sonrasinda da depresyona yol açtığını bulgulamışlardır. Yüksek düzeydeki depresyonlu bireyler düşünce süreçleri üzerindeki kontrollerinin çoğunu kaybetmekte ve olumsuz otomatik düşüncelerin baskısı altına girmektedirler (Gotlib ve Coyne, 1983). Bir diğer araştırmada ODÖ ile Beck Umutsuzluk Ölçeği arasındaki ilişkinin pozitif yönde olduğu ortaya konulmuştur (Corey, 2008; Dinçer ve Derelioğlu, 2005). Olumsuz otomatik düşünceler, kaygıyı ve depresyonu 
artırır ve umutsuzluk gibi sıkıntılara da yol açabilirler (Tümkaya, Çelik ve Aybek, 2008; Schniering ve Rapee, 2004). Bu bulgulara ek olarak olumsuz otomatik düşüncelerin umutsuzluk değişkenini yordadığı ortaya konmuştur.

Öte yandan sonuçlara göre Yaşam Projesi’nin bağımlı değişkenleri (umut vb.) ile olumsuz otomatik düşünceler arasında da ilişkisellik saptanmıştır. Ancak uyumsuzluk haricinde ODÖ alt faktörlerinin Yaşam Projesini yordamadığı bulgulanmıştır. Bulgulara göre ayrıca uyumsuzluk ve ümitsizlik ODÖ değişkenleri haricinde umut değişkenini yordayan başka bir ODÖ değişkeninin olmadığı görülmüştür. Sonuçlar, Kumcağız, Şahin, Alakuş ve Akbaş'ın (2017) yaptıkları araştırmayı destekler niteliktedir. Kumcağız ve arkadaşları tarafından (2017) umut ile olumsuz otomatik düşünceler arasında orta düzeyde anlamlı ilişki bulunsa da olumsuz otomatik düşüncelerin umut değişkenini yordamadiğ 1 saptanmıştır. BaBamiri ve ark. (2011) ve Akbaş'ın (2017) çalışmalarında da benzer sonuçlara erişilmiştir.

Umut değişkeni ve umutsuzluk değişkeni üzerinde olumsuz otomatik düşüncelerin aynı şekilde etkili olmadıkları görülmektedir. Sonuçlara göre çalışanların olumsuz otomatik düşüncelere sahip olması onların umutsuzluğunu artırdığını göstermekte, ancak yaşam projelerine etki etmemektedir. Ayrıca çalışanların olumsuz otomatik düşünceleri ile umutları arasında zayıf düzeyde ilişkisellik bulunmasına rağmen olumsuz otomatik düşüncelerin, uyumsuzluk ve ümitsizlik haricinde yordayıcı rolü bulunmamaktadır. Çalışmanın sonuçlar değerlendirildiğinde, psikolojideki pozitif değişkenleri (yaşam projesi, umut vb.) ve bilişsel davranışçı terapinin temel unsurları (olumsuz otomatik düşünceler vb.) arasında güçlü bir sebep sonuç ilişkisinin ortaya konulamadığı söylenebilir. Ancak bu sonuç araştırmanın veri seti ile sinırlıdır.

$\mathrm{Bu}$ bulgular 1şığında iki konuda eleştiri yapılabilir. Birincisi son yıllardar yapılan çalışmalarda pozitif psikoloji unsularının BDT terapilerinde kullanılmasının önerildiği araştırmalar ve örnek müdahale programlarının ortaya çıktığı görülmektedir (Bannink, 2013; Greenberg, 2015; Prasko, Hruby, Holubova, Latalova, Vsykocilova, Slepcky, Ociskova ve Grambal, 2015). Ne var ki bu ve geçmişteki benzer araştırmalarda ortaya konulduğu gibi BDT unsurlarının pozitif psikoloji değişkenleri ile ilgili ilişkisellik ve yordayıcılık rolünü ortaya koyan çalışmalara ihtiyaç olduğu açıktır. İkincisi, Beck yaklaşımı olarak bilinen bilişsel terapi yaklaşımında yaygın olarak kullanılan Beck Umutsuzluk Ölçeği ve Otomatik Düşünceler Ölçeği gibi ölçme araçlarının 'kavramsallaştırdıkları' psikolojik yapıların birbilerine oldukça benzerlik göstermesinin doğurduğu sakıncalardır. Bu sakıncalardan biri de örneğin pozitif psikoloji unsurlarının BDT terapilerinde değerlendirilmesinin zorlaşması olabilir çünkü BDT, kavramsallaştırdığı yapılarla sadece işlevsel olmayan ve olumsuz psikolojik yapılarla ilgilenmekte pozitif psikolojik unsurlara yeteri kadar adapte olamamaktadır.

$\mathrm{Bu}$ çalışma bazı sınırlıklar içermektedir. Araştırmada incelenen olumsuz otomatik düşünceler, yaşam projesi ve umutsuzluk değişkenleri; ODÖ, yaşam ölçeği ve Beck umutsuzluk ölçeklerinin ölçtüğü niteliklerle sınırlı kalmıştır. Araştırmanın örnekleminin kolaydan örnekleme yöntemiyle seçilmiş olması araştırma sonuçlarının kısıtlı olarak yaygınlaştırılabileceğini gösterir. Gelecekteki çalışmalarda olumsuz otomatik düşüncelerin farklı gruplarda ve farklı analiz yöntemleri ile (örn: deneysel çalışmalarla) psikolojideki pozitif unsurlarla birlikte test edilmesi önerilir. 


\section{KAYNAKÇA}

Artıran, M. (2015). Akılcı Duygucu Davranışçı Kuram ve Öz-Belirlenim Kuramı Çerçevesinde Yeni Bir Ölçek: Akılcl-Duygucu Öz-Belirlenim (ADÖP) Ölçeğinin Geliştirilmesi. Yayınlanmış Doktora Tezi. İstanbul Arel Üniversitesi. İstanbul.

Aydın, B. (1990). Üniversite öğrencilerinde depresyon, bilişsel çarpıtmalar ve akademik başarı. Marmara Üniversitesi Atatürk Ĕ̈itim Fakültesi Eğitim Bilimleri Dergisi. 2, 27-36.

Balc1, A. (2009). Sosyal bilimlerde araştırma: yöntem, teknik ve ilkeler. Ankara: PegemA Yayınevi.

BaBamiri, M., Vatankhah, M., Jahandizi, H. M., Nemati, M. ve Darvishi, M. (2013). The Relationship between Coping Styles, Negative Automatic Thoughts, and Hope with Happiness in Addicts of Ahvaz Drug Abuse Rehabilitation Clinics in 2011. Journal of Zanjan University of Medical Sciences. Volume 21, Issue 84 (3-2013)

Bannink, P. (2013). Are you ready for positive cognitive behavioral therapy? The Journal of Happiness \& Well-Being. 1(2)

Beck, A.T. (1963). Thinking a depression. Arch Gen Psychiatry. 9: 324-333

Beck, A. T. (1976). Cognitive Therapy And Emotional Disorder. International University Press. New York.

Beck, A. And Emery, G. (2011). Anksiyete Bozuklukları Ve Fobiler. Litera Yayınc1lı. İstanbul.

Beck, J. (1995). Cognitive Therapy: Basics And Beyond. The Guilford Press. New York.

Beck J. (2001). Bilişsel Terapi: Temel Illkeler Ve Ötesi. (Çev. N Hisli Şahin), (Çev. Ed. F. Balkaya, A İlden Koçkar), Türk Psikologlar Derneği Yayınları. Ankara.

Corey, G. (2008). Psikolojik Danışma, Psikoterapi Kuram Ve Uygulamaları (7. Baskı, Çev. T. Ergene). Mentis Yayıncilık. Ankara.

Çakar, F. S. (2014). Otomatik Düşüncelerin Umutsuzluk Üzerindeki Etkisinin İncelenmesi: Benlik Saygısının Aracılık Rolü. Kuram Ve Uygulamada Ĕgitim Bilimleri. 14(5), 116.

DiGiuseppe, R. A., Doyle, K. A., Dryden, W. Backx, W. (2014). A Practitioner's Guide to Rational Emotive Behavior Therapy (3rd Ed.). Oxfort University Press. New York. Türkçe Çevirisi: Uygulamacının Bir Klavuzu: Rasyonel Duygucu Davranışçı Terapi. (Çeviren: Murat Artıran). Nobel Yayınları. İstanbul.

Dinçer, D. Ve Derelioğlu, Y. (2005). Üniversite Sınavına Hazırlanan Lise Son Sınıf Öğrencilerinin Umutsuzluk Düzeylerinin İncelenmesi. V111. Ulusal Psikolojik Danışma Ve Rehberlik Kongresi’nde Sunulan Bildiri, Marmara Üniversitesi, İstanbul.

Durak, A. ve Palabıyıkoğlu R. (1994). Beck Umutsuzluk Ölçeği Geçerlilik Çalışması, Türk Psikoloji Dergisi. Say1 2.

Eğinli, A. T. (2009). Çalışanlarda İş Doyumu: Kamu Ve Özel Sektör Çalışanların İş Doyumuna Yönelik Bir Araştırma. Atatürk Üniversitesi İktisadi Ve İdari Bilimler Dergisi. C.23, S.3, S.42.

Gladding, S. T. (2015). Family therapy: History, theory, and practice. Pearson.

Ellis, A. (2003). Similarities And Differences Between Rational Emotive Behavior Therapy And Cognitive Therapy. Journal of Cognitive Psychotherapy: An International Quarterly, 17, 225 - 240

Ellis, A. (1994). Reason and emotion in psychotherapy (Rev. Ed.). Secaucus, NJ: Birscj Lane.

Fennel, M. (1996). Depression, In Hawton, K. (Ed.). Cognitive Behaviour Therapy For Psychiatric Problems, (169-235), Oxford University Press. New York.

Field, A. (2000). Discovering statistics using IBM SPSS statistics. London: Sage Publications. 
Greenberg, D. (2015). The Link Between Cognitive Behavior Therapy and Positive Psychology. Erişim tarihi: 15 Ekim 2018, https://beckinstitute.org/the-link-betweencognitive-behavior-therapy-and-positive-psychology/

Gotlib, I.; Coyne, J. (1983). The role of cognition in depression: A critical appraisal. Psychological Bulletin. 94(3)

Hankin, B. L.,Abramson, L.Y.,Siler, M. (2001). A prospective test of the hopelessness theory of depression in adolescence. Cognitive Therapy and Research, 25(5), 607 - 632.

Haran, S., Aydın, O. (1995). Depresyon, Umutsuzluk, Sosyal Beğenirlik ve Kendini Kurgulama Düzeyinin İntihar Fikirleri ile İlişkisi. Kriz Dergisi. 3(1-2), 218 - 222.

Henkel, V., Mergl, R., Kohnen, R., Maier, W., Möller, H. J., \& Hegerl, U. (2003). Identifying depression in primary care: a comparison of different methods in a prospective cohort study. Bmj, 326(7382), 200-201.

Himle, J.; Steinberger, E., Laviolette, W. \& Golenberg, Z. (2013). Work-Related CognitiveBehavioral Therapy for Unemployed Persons with Social Anxiety. The Society for Social Work and Research. Annual Conference

Kocayörük, E., Altıntaş, E., Şimşek, Ö. F., Bozanoğlu, İ., Çelik, B. (2013). Üniversite Öğrencilerinin Zaman Perspektifli İyi-Oluş Düzeyleri: Kümeleme Analizi İncelemesi Ontological Wellbeing Of University Students: A Cluster-Analysis Approach. Ĕ̈itim Fakültesi Dergisi. 33(3):550-564

Kumcağız, H., Şahin, C., Alakuş, K. ve Akbaş, M. (2017). Yeme Tutumlarını Yordamada Umut Ve Olumsuz Düşüncelerin Rolü. International Journal Of Eurasia Social Sciences. Vol: 8, Issue: 29, pp. (939-954).

Murdock, N. L. (2012). Psikolojik Danışma Ve Psikoterapi Kuramları. (Çev. Ed.: Akkoyun, F.) Nobel Yayıncilik. Ankara.

Onay, M., \& Kılcı, S. (2011). İş stresi ve tükenmişlik duygusunun işten ayrılma niyeti üzerine etkileri: Garsonlar ve aşçıbaşılar. Organizasyon ve Yönetim Bilimleri Dergisi, 3(2).

Özdemir, S., \& Muradova, T. (2008). Örgütlerde Motivasyon Ve Verimlilik İlişkisi. Journal of Qafqaz University, (24).

Snyder, C., C.R., Harris, C.R., J.R. Anderson, J.R., Holleran, S.A., Irving, L.M., Sigmon, S.X., Bshinobu, L., Gibb, J., Langelle, C., Harney, P. (1991). The Will and the Ways: Development and Validation of an Individual-Differences Measure of Hope. Journal of Personality and Social Psychology, 60, 4, 570-585.

Padesky, C. A. \& Mooneyi K. A. (2012). Strengths-Based Cognitive-Behavioural Therapy: A Four-Step Model to Build Resilience. Clinical Psychology and Psychotherapy. 19, 283-290

Prasko, J., Hruby, R., Holubova, M., Latalova, K., Vsykocilova, J., Slepcky, M., Ociskova, M. ve Grambal, A. (2015). Positive cognitive behavioral therapy. Activitas Nervosa Superior. Rediviva ISSN 1337-933X

Rana, M., Sthapit, S. \& Sharma, V.D. (2017). Assessment of Automatic Thoughts in Patients with Depressive Illness at a Tertiary Hospital in Nepal. Journal of Nepal Medical Association. 56(206):248-255.

Snyder, C. R., İlardi, S., Cheavens, J. S., Michael, S. T. (2000). The Role of Hope in Cognitive-Behavior Therapies. Cognitive Therapy and Research. 24. 747-762. 10.1023/A:1005547730153.

Kumcağız, H., Şahin, C., Alakuş, K. ve Akbaş, M. (2017). Yeme Tutumlarını Yordamada Umut Ve Olumsuz Düşüncelerin Rolü, International Journal Of Eurasia Social Sciences, Vol: 8, Issue: 29, pp. (939-954).

Savaşır, I., ve Şahin, N. H. (1997). Bilişsel-Davranışçı Terapilerde Değerlendirme: S1k Kullanılan Ölçekler. Türk Psikologlar Derneği Yayınları, 9. 
Schniering, C. A. ve Rapee, R. M. (2004). The Relationship Between Automatic Thoughts And Negative Emotions In Children And Adolescents: A Test Of The Cognitive Content-Specificity Hypothesis. Journal Of Abnormal Psychology, 113(3), 464-470.

Seligman, M. E. P., ve Csikszentmihalyi, M. (2000). Positive Psychology: An Introduction. American Psychologist, 55, 5-14.

Stiles, T.C. \& Götestam, K.G. (1989). The role of automatic negative thoughts in the development of dysphoric mood: An analogue experiment. Cognitive Theory and Research. 13: 161. https://doi.org/10.1007/BF01173270

Şahin, N. H., Şahin, N. (1992). Reliability And Validity Of The Turkish Version Of The Automatic Thoughts Questionnaire. Journal of Clinical Psychology, 48(3), 334-340.

Sönmez V. \& Alacapınar, F. (2011). Bilimsel araştırma yöntemleri. Anı Yayıncılık. Ankara.

Tatlidil, H. (2002). Uygulamall çok değişkenli istatistiksel analiz. Akademi Matbaası. Ankara.

Tümkaya, S., Hamarta, E., Deniz, M. E., Çelik, M., \& Aybek, B. (2008). Duygusal zeka mizah tarzı ve yaşam doyumu: Üniversite öğretim elemanları üzerine bir araştırma. Türk Psikolojik Danışma ve Rehberlik Dergisi, 3(30), 1-18.

Tümkaya, S., Çelik, M., ve Aybek, B. (2011). Lise Öğrencilerinde Boyun Eğici Davranışlar Otomatik Düşünceler Umutsuzluk Ve Yaşam Doyumunun İncelenmesi. Çukurova Üniversitesi Sosyal Bilimler Enstitüsü Dergisi, 20(2).

Usta, H. K. (2017). Ergenlerde Benlik Saygısının Algllanan Anne-Baba Tutumlarl Ve Olumsuz Otomatik Düşüncelerle Yordanması: Samsun İli Örneği. Yüksek Lisans Tezi. T.C. Bahçeşehir Üniversitesi. İstanbul. 